\section{Migration of a transcatheter aortic valve in the left ventricular outflow tract}

A 75-year-old female with symptomatic aortic stenosis, endstage renal failure and peripheral vascular disease underwent due to high operative risk for conventional aortic valve replacement (logistic EuroSCORE predicted mortality 36\%, STS Score 21\%),
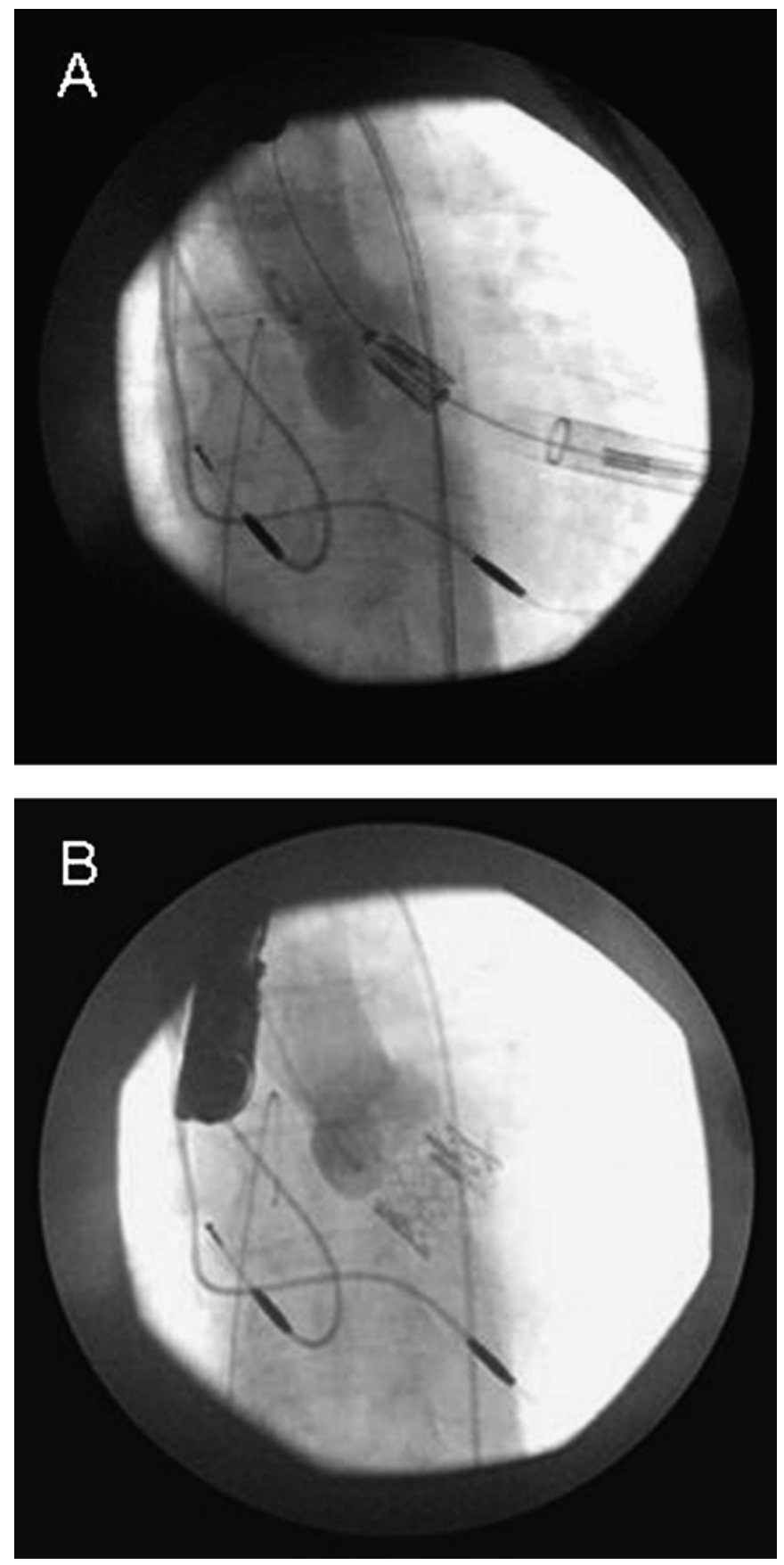

Figure 1 Angiogram of the proximal portion of the aorta ascendens. (A) Edwards SAPIEN valve (23 $\mathrm{mm})$. This was placed under rapid pacing within the aortic annulus using the transapical approach. See supplementary video I for animated images of the placement and migration of the valve towards the left ventricle. (B) Prosthesis. After migration, the final position of the prosthesis was within the left ventricular outflow tract underneath the native aortic valve.
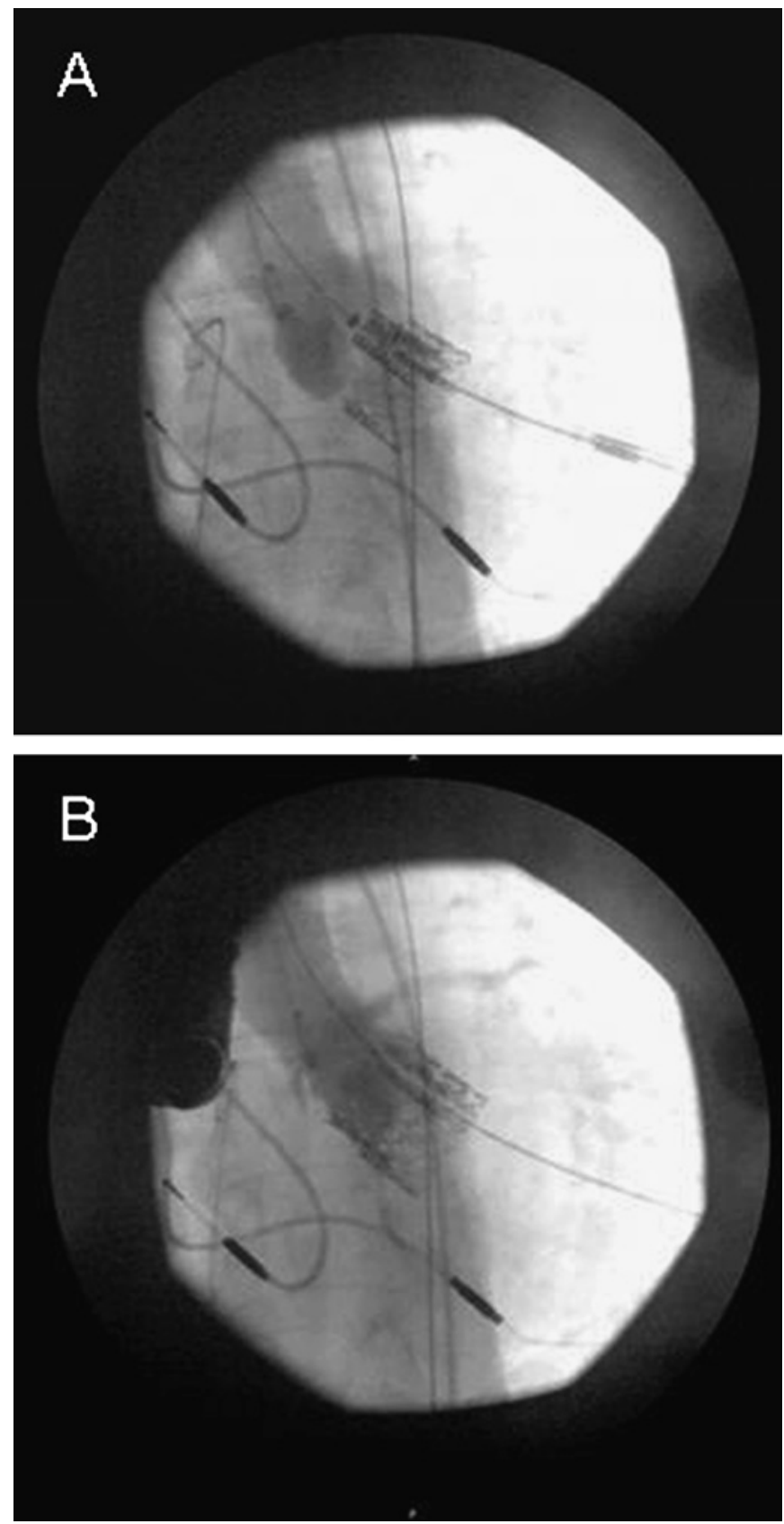

Figure 2 Angiogram of the proximal portion of the aorta ascendens. (A) Implantation of a second $23 \mathrm{~mm}$ Edwards SAPIEN valve, performed with an overlay of $1 / 3$ to the first valve. See supplementary video II for animated images. (B) Postprocedure angiogram, showing good valve function with no residual aortic regurgitation. See supplementary video III for animated images.

transapical aortic valve implantation using a $23 \mathrm{~mm}$ Edwards SAPIEN valve.

Angiography of the ascending aorta revealed deployment of the valve within the aortic annulus, but soon after migration towards the left ventricular outflow tract underneath the native aortic valve (figure $1 \mathrm{~A}, \mathrm{~B}$, supplementary video 1). Transesophageal echocardiography and fluoroscopy revealed no residual aortic insufficiency but remaining aortic stenosis produced by the native aortic valve. The mitral valve was not compromised by the migrated prosthesis. To keep the prosthesis in place and to treat the remaining aortic stenosis, a second $23 \mathrm{~mm}$ Edwards SAPIEN valve was implanted with an overlay 
of $1 / 3$ to the first valve (figure $2 \mathrm{~A}$, supplementary video 2 ). The postprocedure echocardiography and angiography showed good valve function with no residual aortic insufficiency (figure $2 \mathrm{~B}$, supplementary video 3 ). The patient was transferred to the intensive care unit haemodynamic stable and was extubated $4 \mathrm{~h}$ later.

A more liberal use of transcatheter aortic valve implantation necessitates as a prerequisite the potential management of unexpected events for a beneficial outcome of this highly challenging task.

\section{R G Seipelt, G Hanekop, W Schillinger}

Correspondence to Ralf G Seipelt; rseipelt@med.uni-goettingen.de

- Additional videos are published online only. To view these files, please visit the journal online (http://heart.bmj.com).

Competing interests RGS works partially as a Proctor for Edwards Lifesciences.

Provenance and peer review Not commissioned; not externally peer reviewed.

Published Online First 23 August 2010

Heart 2010;96:1949-1950. doi:10.1136/hrt.2010.202465 


\section{HEART}

\section{Migration of a transcatheter aortic valve in the left ventricular outflow tract}

R G Seipelt, G Hanekop and W Schillinger

Heart 2010 96: 1949-1950 originally published online August 23, 2010

doi: 10.1136/hrt.2010.202465

Updated information and services can be found at:

http://heart.bmj.com/content/96/23/1949.full.html

\section{These include:}

Data Supplement

"Web Only Data"

http://heart.bmj.com/content/suppl/2011/03/03/hrt.2010.202465.DC1.html

Email alerting

Receive free email alerts when new articles cite this article. Sign up in service the box at the top right corner of the online article.

Notes

To request permissions go to:

http://group.bmj.com/group/rights-licensing/permissions

To order reprints go to:

http://journals.bmj.com/cgi/reprintform

To subscribe to BMJ go to:

http://group.bmj.com/subscribe/ 